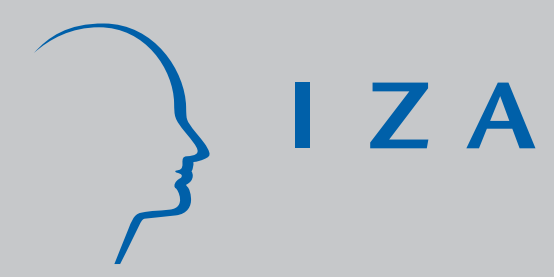

IZA DP No. 2457

Immigrants in a Booming Economy:

Analysing their Earnings and Welfare Dependence

Alan Barrett

Yvonne McCarthy

November 2006 


\title{
Immigrants in a Booming Economy: Analysing their Earnings and Welfare Dependence
}

\author{
Alan Barrett \\ Economic and Social Research Institute \\ and IZA Bonn \\ Yvonne McCarthy \\ Economic and Social Research Institute
}

Discussion Paper No. 2457

November 2006

\author{
IZA \\ P.O. Box 7240 \\ 53072 Bonn \\ Germany \\ Phone: +49-228-3894-0 \\ Fax: +49-228-3894-180 \\ E-mail: iza@iza.org
}

\begin{abstract}
Any opinions expressed here are those of the author(s) and not those of the institute. Research disseminated by IZA may include views on policy, but the institute itself takes no institutional policy positions.
\end{abstract}

The Institute for the Study of Labor (IZA) in Bonn is a local and virtual international research center and a place of communication between science, politics and business. IZA is an independent nonprofit company supported by Deutsche Post World Net. The center is associated with the University of Bonn and offers a stimulating research environment through its research networks, research support, and visitors and doctoral programs. IZA engages in (i) original and internationally competitive research in all fields of labor economics, (ii) development of policy concepts, and (iii) dissemination of research results and concepts to the interested public.

IZA Discussion Papers often represent preliminary work and are circulated to encourage discussion. Citation of such a paper should account for its provisional character. A revised version may be available directly from the author. 


\section{ABSTRACT \\ Immigrants in a Booming Economy: Analysing their Earnings and Welfare Dependence*}

Ireland's exceptional economic growth in recent years has led to an influx of immigrants. Given the favourable economic climate into which these immigrants are arriving, it is interesting to ask how their earnings and welfare dependence compare with the native population. To the extent that strong economic growth produces good labour market opportunities for immigrants, earnings disadvantages may be lessened and any tendency towards welfare dependence may be reduced. Data from a nationally representative sample drawn in 2004 are used to assess the earnings of immigrants in Ireland relative to the native population and also the rate of welfare receipt across the two groups. Immigrants are found to earn 18 percent less than natives, controlling for education and years of work experience. However, this single figure hides differences across immigrants from English-speaking and non-English speaking countries. We also find evidence of a wage gap for immigrants with third level educations, relative to comparable natives. On average, immigrants are half as likely to have been in receipt of social welfare payments in the previous twelve months relative to natives. A difference in welfare participation remains when we control for the higher education attainment of immigrants.

JEL Classification: J61

Keywords: immigrants' earnings, immigrants' welfare participation, Ireland

Corresponding author:

Alan Barrett

Economic and Social Research Institute

Whitaker Square, Sir John Rogerson's Quay

Dublin 2

Ireland

E-mail: Alan.Barrett@esri.ie 


\section{Immigrants in a Booming Economy: Analysing their Earnings and Welfare Dependence}

\section{Section 1: Introduction}

Since the mid-1990s Ireland has enjoyed exceptional rates of economic growth. Between 1994 and 2004, growth in real GNP averaged over 6 percent per annum. Over the same period, the rate of unemployment fell from close to 15 percent to under 5 percent. This strong economic performance has, in turn, led to an inflow of immigrants. In this paper, we examine the earnings of these immigrants relative to natives and also the extent to which immigrants draw on welfare services, again relative to natives. In so doing, we are using Ireland as a new and interesting case to enable us to develop further our knowledge of immigrant experiences.

Before outlining in detail the contents of the analysis and the structure of the paper, we should set out precisely why Ireland offers an interesting case study. In addition to Ireland's growth performance, noted above, there are some notable dimensions to Ireland's immigration experience. First, Ireland is unusual in terms of the speed with which the non-national percentage of its population has risen. In the Census of 2002, 7 percent of the population was found to be non-nationals. In the Census of 2006, the corresponding figure was 10 percent. We can get a sense of how exceptional this has been if we compare the Irish experience with that of the UK where the non-national population grew by 2 percentage points over a thirty-year period, between 1960 and 1990 (Bell, 1997).

A second unusual dimension of Ireland's migration experience is the speed with which it turned from being a country of out-migration to being a country of inmigration. As shown in Figure 1, as recently as the early 1990s Ireland was experiencing a net outflow. As the population at the time was only 3.5 million, the outflows in 1988 and 1989 represented over 1 percent of the population. This meant that the rate of outflow in the late 1980s was high by international standards.

Figure 1 here 
A third unique feature of immigration into Ireland has been the high levels of education among the immigrants. As shown by Barrett et al (2002) and Barrett et al (2006), immigrants in Ireland have notably higher levels of education than the domestic population. This is in contrast to the experience, for example, in the US where immigrants are generally less skilled than the native population.

Given these three dimensions of Ireland's immigration experience, it is of interest to explore the experiences of immigrants in Ireland. As we are looking at a group that is (a) highly educated and (b) arriving into a rapidly growing economy, we might expect that some of the difficulties experienced by immigrants elsewhere may not be observed in Ireland. We look at two dimensions of immigrant experiences using a nationally representative dataset. We look at earnings and the take-up of social welfare benefits and we ask whether there are differences between immigrants and natives in respect of each. The data used are from the Irish component of the EU's Survey of Income and Living Conditions (EU-SILC) for 2004. The issues of earnings and welfare participation have not been explored to date using a nationally representative sample for Ireland. Instead, much of the work on topics such as these have only looked at certain sub-groups of the immigrant population such as work permit holders (Ruhs, 2005) or asylum seekers (Fanning et al, 2000), both of which are small minorities of the total immigrant population.

In looking at earnings, we build on the work of Barrett et al (2006), one of the few other studies to look at immigrants in Ireland using a nationally representative sample. They studied occupational attainment and identified what they described as an “occupational gap” between natives and immigrants. By this they meant that immigrants appeared to hold occupations that were at a lower level compared to those held by natives, controlling for characteristics such as age and education. Here, we look at this issue of labour market achievement by analysing earnings. In looking at welfare take-up, we are addressing an issue that has not been studied to date for immigrants in Ireland, to our knowledge, but which is of great importance. As noted by Borjas (1995), the impact of immigrants on the public finances is a crucial element of their overall economic impact. Social welfare is one route through which they can have an impact and so an investigation of welfare participation can contribute to a broader understanding of immigrant impacts. 
The paper is structured as follows. In Section 2, we discuss the international literature on immigrant earnings and welfare participation with a view to providing a context for our empirical analysis. In Section 3, we discuss the data used in the analysis and present some initial descriptive statistics. In Section 4, we present our findings with respect to the earnings of immigrants relative to those of natives. In Section 5, we report on the welfare-related component of the analysis. In Section 6, we provide a summary and offer conclusions.

\section{Section 2: The Literature}

One of the earliest papers on the earnings of immigrants (Chiswick, 1978) sets out the thinking which underpins much of the subsequent work on immigrant earnings so it is useful to begin with a discussion of this paper. The Chiswick view sees immigrants suffering an initial wage disadvantage relative to natives when they arrive in the host country. The reason for this is that immigrants initially lack location-specific human capital such as language skills. Over time, immigrants will invest in acquiring location-specific human capital and so their wages will converge on those of natives. A further implication of the Chiswick view is that immigrants from countries that are similar to the host country in terms of labour market features will suffer a lower earnings disadvantage relative to immigrants from dissimilar countries.

Chiswick's empirical work appeared to show that the wages of immigrants not only converged on those of natives but also overtook them. He explained this as being the result of unobserved characteristics on the part of immigrants such as drive and ambition that allowed them to excel in the host country. However, this empirical finding was called into question by Borjas (1985) who showed that the apparent increase in immigrant earnings over time was actually the result of a change in the nature of the immigrant inflow. He showed that more recent waves of immigrants into the United States were performing less well than the earlier arrivals and that the pattern that Chiswick had observed was the result of a cohort effect and not an assimilation effect. Any convergence between immigrants and natives was limited.

As Borjas (1985 and 1987) called into question the earnings convergence hypothesis of Chiswick, the question of whether immigrants earn more, less or the same as 
natives has been addressed in a number of empirical studies. Here, we will outline the results of a selection but a more comprehensive review can be found in Borjas (1999).

Bell's (1997) analysis of immigrant earnings in the UK shows that white immigrants enjoy a wage premium over white natives when they arrive in the UK. This suggests that any lack of location-specific human capital at that point is more than compensated for by other productivity-increasing unobservable attributes. This is in line with the Chiswick hypothesis of immigrants being positively selected from the home population. Black immigrants who have accumulated labour market experience prior to reaching the UK suffer the largest earnings disadvantage relative to comparable natives. This suggests that previous labour market experience is considered to be specific to the home country and so not rewarded in the UK. Black immigrants without prior experience do not suffer as much of a disadvantage in the UK, again relative to comparable natives.

Shields and Wheatley-Price (1998) also looked at immigrants in the UK and, like Bell (1997), found differences in the experiences of white and non-white immigrants. They also found that part of the immigrant-native wage difference could be explained by different returns to human capital acquired in the UK and elsewhere. McDonald and Worsnick (1998) examine the earnings of immigrants in Canada and find an earnings gap relative to natives. Their analysis shows that differences in job tenure explain a significant proportion of this gap. They also show that the rate of earnings convergence for each immigrant cohort relative to natives is partly determined by macroeconomic conditions. Immigrants who arrived in Canada in the 1980s faced poorer labour market conditions than earlier arrivals and this appears to have impacted upon their assimilation.

Chiswick and Miller (2002) focus on the language fluency in their analysis of U.S. immigrant earnings. They show that there is a 14 percent wage difference between immigrants from non-English speaking countries who are fluent and non-fluent in English. They also show that there is evidence of complementarity between language ability and other forms of human capital. For the UK, Dustmann and Fabbri (2003) find a fluency-related earnings disadvantage of around 20 percent. 
With regard to welfare participation, two papers illustrate the issues and the results. In the case of both papers, the authors begin with the observation that immigrants are more likely to be in receipt of welfare services relative to natives. They then aim to see if these unadjusted differences can be explained by the characteristics of immigrants. Hansen and Lofstrom (2003) find that for Sweden the higher participation by immigrants remains, controlling for observable characteristics. In contrast, Riphahn (2004) finds that the relatively higher participation in welfare programmes by immigrants in Germany can be fully explained by differences in the characteristics of immigrants and natives. With rates of unemployment and single parenthood found to be higher among immigrants in Germany, these two factors explained much of the unadjusted difference in welfare participation.

\section{Section 3: Data and Descriptive Statistics}

The data on which the analysis below is based come from the EU Survey on Income and Living Conditions (EU-SILC) for 2004. A full description of the sampling methodology can be found in Central Statistics Office (2005) but here we will set out the broad features of the survey. The EU-SILC is a voluntary survey of private households and is carried out under EU legislation. To date, it has been used mainly to provide information on the rates of poverty and deprivation in Ireland (CSO, 2005). The survey seeks to provide a nationally representative sample of households. It does so by first creating a sample of 2600 small areas and then selecting a random sample of households within each block. About 130 households were surveyed each week during the twelve months of 2004, resulting in a sample of 5,477 households and 14,272 individuals.

For each individual, the survey contains information on variables such as age, education, labour force status and earnings. It also contains information on whether or not each individual is in receipt of a wide range of social welfare payments. Crucially for our purposes, the place of birth and citizenship of each respondent is provided and we use these to identify the immigrants in the sample. If an individual reports themselves as having been born in Ireland and as being an Irish citizen, we code them as being a native. If an individual reports that they were born outside of Ireland and 
that they are not Irish citizens, we code them as being immigrants. In addition, we take their reported citizenship to describe where they are from ${ }^{2}$.

It should be borne in mind that the immigrants we observe in the sample will have entered Ireland through a number of routes. For citizens of the EU, there are no restrictions on movement to Ireland and on working there. As the data were collected through 2004, and as full access to Ireland's labour market was granted to citizens of the accession countries in May 2004, it will be uncertain as to whether the immigrants in our sample from the relevant countries came here as EU citizens (post-May 2004) or through other means (pre-May 2004). Other admission routes include work permits and family re-unification measures.

Before proceeding to the presentation of the econometric analysis below, we will present some descriptive statistics from the data. In the tables below we present sample means for both the immigrants and natives within the sample. We also show the means for the same variables for immigrants in the CSO's Quarterly National Household Survey (QNHS) from the second quarter of 2004. The QNHS is based on a sample of 39,000 households and so provides a much larger sample than the EUSILC. In the EU-SILC, immigrants make up 4.3 percent of the sample. From the Census of 2002, we know that non-nationals made up 7 percent of the population at that time so immigrants are under-represented in our data. Given this undercount of the number of immigrants, it is desirable that there be no systematic biases across the broad socio-economic variables. For this reason, comparisons with information from the QNHS are useful in assessing the degree to which the immigrants in the sample are representative of immigrants in Ireland generally. As will be seen, in terms of the variables of greatest interest, i.e. work status and education, the distributions are similar.

In Tables 1 and 2, we present information on the age and gender distributions of the natives and immigrants in the sample and of the immigrants in the QNHS. In the case of both the EU-SILC and the QNHS, immigrants are shown to be concentrated in the age groups 25-34 and 35-44. However, the QNHS counted a bigger proportion of

\footnotetext{
${ }^{2}$ One group that we exclude from the analysis are people who are Irish citizens but who were not born here.
} 
immigrant children whereas the EU-SILC counted a bigger proportion in the older age groups. In the case of gender, the EU-SILC shows a higher proportion of female immigrants relative to the QNHS. While it would be preferable to see a greater degree of similarity between the QNHS immigrants and the EU-SILC immigrants, we do at least have a group for our analysis that are concentrated in the same age categories as with the QNHS and that are broadly balanced in terms of gender.

Tables 1 and 2 here

In Table 3, we turn to the work status of the natives and the immigrants. Here, there is a greater degree of similarity between the immigrants in the EU-SILC and the immigrants in the QNHS. The participation rate among immigrants is 57.5 percent in the EU-SILC and 55.8 percent in QNHS. The unemployment rate is lower for the EUSILC immigrants but both groups are shown to have a higher rate of unemployment relative to the native population.

Table 3 here

The last variable that we look at is education. In Table 4, we show the distribution of educational qualifications for the labour force participants of the three groups, with qualifications broken down into three categories: less than leaving certificate, leaving certificate/non-degree third level and third level degree. The picture to emerge is that of an immigrant population that is relatively well educated when compared to the native population. Both the EU-SILC and the QNHS show that over 40 percent of the immigrant labour force have third level degrees, compared to just under 20 percent of the native labour force. This finding is in line with Barrett et al (2006) and so shows again the notably high level of education among Ireland’s immigrants.

Table 4 here

\section{Section 4: Earnings}

In this section, we present the results of the analysis of the earnings of immigrants relative to natives. Our earnings measure is constructed using two responses in the survey. Respondents were asked what their usual earnings were for a reference period, with the respondent choosing the reference period, for example a week. They were 
also asked what their usual hours worked were in the same reference period. Combining the two responses, we calculated hourly earnings for each individual.

The mean hourly wage for natives in the sample is just over $€ 25$; for immigrants, the corresponding figure is just over $€ 17$. These average figures suggest lower earnings on the part of immigrants but in order to investigate this systematically, we need to employ regression analysis. Table 5 contains the results from three regressions in which we estimate the coefficients in standard Mincer-type wage equations. The dependent variable in each case is the log of hourly wages. Each regression contains controls for education and experience and also dummy variables indicating immigrants of different types. We should note that as we are restricting the analysis to individuals who report their earnings plus all other variables included in the analysis, the number of immigrants included at this point falls to 183. When we go on to subdivide the immigrants into different groups, the cell sizes fall again and this places a limit on our analysis. We will now discuss each model in turn.

In Model 1, we include all immigrants and all natives and use a single dummy variable to indicate who is an immigrant. Before discussing the coefficient on this variable we will look briefly at the other coefficients. Gender is a dummy variable equal to one if the individual is male. The finding of a 12 percent wage advantage for men is in line with other studies. Years worked is a continuous variable and measures the number of years that each individual has spent at work since their first regular job. The 4 percent wage premium for every year worked is reasonable. We included a squared value for this variable as is usual but it turns out to have no explanatory power.

The last two variables are dummy variables indicating individuals with second and thirds level qualifications. As the omitted education category is people with primary qualifications or none, the coefficients can be interpreted as showing returns to secondary and tertiary education relative to having a more basic education. The coefficients on these variables are both positive and significant, with third level having a higher value, all as expected. 
Turning to the immigrant dummy in Model 1, the coefficient implies that immigrants in Ireland earn 18 percent less than natives on average, controlling for education, experience and gender. Based on Barrett et al (2006), we know that this average figure is likely to conceal important differences across immigrant groups. In Model 2, we look at immigrants from English-speaking and non-English speaking countries separately to see if this is the case ${ }^{3}$. The coefficient for the immigrants from English speaking countries suggests that these immigrants may earn a little less than native employees but as the coefficient is not statistically significant, we cannot be definitive on this point. In the case of immigrants from non-English-speaking countries, a stronger result emerges. These immigrants experience a 31 percent wage disadvantage relative to comparable natives.

As a final exercise in this stage of the analysis, we looked within the non-English speaking group. We created three dummy variables indicating immigrants from EU accession countries (EU-10), from the EU-15, less Ireland and the UK (EU-13) and from non-EU countries (non-English/non-EU). We re-ran the regression excluding all other immigrants so the coefficients on each of these three dummy variables should be interpreted as the earnings of these groups relative to natives. The results suggest that the wage disadvantage is particularly pronounced for immigrants from the EU-10, at 45 percent. However, the wage disadvantage for the EU-13 is also large, at 27 percent. While this might be surprising, it is in line with findings in Barrett et al (2006) of similar occupational disadvantages for the two groups of European immigrants. For the non-English-speaking/non-EU group the wage disadvantage is also 27 percent $^{4}$. The coefficients on these three dummy variables are all statistically different from zero but not from each other.

Table 5 here

\footnotetext{
${ }^{3}$ Ideally, if we had information on English language ability for each immigrant, we would have used this in the analysis. However, in the absence of such information, we use English-speaking and nonEnglish-speaking countries as proxy variables. The English-speaking countries are the US, the UK, Canada, Australia and New Zealand. Although South Africa might have been added to the list, it is not identified separately from other southern African countries in the data.

${ }^{4}$ It might have been expected that non-English-speaking/non-EU immigrants would have experienced a larger wage gap relative to the EU-13 group. Part of the explanation for this not being the case may be the inclusion of people from Pakistan, India and the Philippines in this category as many immigrants from these countries will speak English.
} 
The next stage in our analysis was motivated by the finding in other papers (such as Shields and Wheatley-Price, 1998) that a part of the immigrant earnings disadvantage could be explained by different returns to human capital acquired in the host and home countries. As our data do not identify where education and experience were acquired, we cannot test for this directly. However, if we assume that a substantial component of immigrants' education and experience was acquired before arriving in Ireland, we can generate some evidence on this point by re-running models of the type shown in Table 5 but this time including interactions between the immigrant dummy variables and the education and experience variables. Given that our sample of immigrants is small (only 183 in total), we use a two-way categorisation of education at this point, third-level degree holders and others. The results are presented in Table 6.

Table 6 here

Model 1 includes a dummy variable capturing all immigrants and an interaction term between immigrant and degree-level education. The estimated immigrant wage gap is now 12 percent, down from the value of 18 percent shown in Table 5, Model 1. If we then turn to the interaction term, we see that the regression produces an estimate of a 17 percent wage gap between immigrants with third level qualifications and natives with the same qualifications. As both of these coefficients are statistically significantly different from zero ${ }^{5}$, it appears to be the case that a part of the immigrant earnings disadvantage is related to immigrants with third level educations being paid less relative to comparable natives. In Model 2 of Table 5, we show the results when an interaction between experience and immigrant is added. As can be seen, very little changes so this interaction does not appear to add anything to our model.

As the analysis presented in Table 5 shows significant differences in the earnings of immigrants from English-speaking and non-English speaking countries, we re-ran Models 1 and 2 of Table 6 for the immigrants from non-English speaking countries only. The results are reported as Models 3 and 4 in Table 6. Looking first at Model 3, the inclusion of the immigrant/education interaction reduces the estimate of the immigrant earnings gap from 31 percent (Model 2 of Table 5) to 26 percent.

\footnotetext{
${ }^{5}$ The p-values for both the immigrant coefficient and the immigrant/third level interaction are 5\%.
} 
However, the coefficient on the immigrant/education interaction term is not significant so we cannot offer any strong conclusion that the earnings of immigrants with third-level degrees from non-English speaking countries differ from those of natives with third level degrees.

Before concluding our analysis of earnings, we should note that we ran the earnings equation for all immigrants including a set of dummy variables controlling for occupation. The inclusion of this set of dummy variables had no effect on the estimate of the immigrant earnings differential; it fell from 18 percent to 16.6 percent but these point estimates are statistically the same. We also ran an equation with both occupations and occupation/immigrant interactions. The estimated immigrant wage gap fell to 11 percent under this specification but was no longer statistically different from zero. As with the interactions between immigrants and education, the small number of observations may well be making it difficult to pick up an effect even if it exists.

\section{Section 5: Welfare}

We now turn to the second broad component of our analysis. As noted in the Introduction, one avenue through which immigrants can impact upon the host country is through the public finances. If immigrants are found to use welfare services more (less) intensively than natives, they will have a negative (positive) impact on the public finances relative to natives. For this reason, we use the data to provide information on the relative usage of social welfare by immigrants and natives.

The data contain information on whether or not individuals received payments under a broad range of categories in the previous twelve months. We limit our interest somewhat and construct a "welfare participation” dummy variable based on whether individuals received payments under one of the following four programmes: unemployment benefits or assistance and disability benefits or assistance. We only look at individuals in the standard working-age cohort and so omit the over 65s. This means of course that we are not considering receipt of old age pensions.

We should note that the group of immigrants would have different welfare entitlements, depending on their length of time in Ireland and the duration of work 
time in particular. Up to May 2004, all EU immigrants had the same entitlements as Irish citizens. However, in May 2004 a two-year residency requirement was introduced. For non-EU immigrants on work permits, should they lose their job, they are no longer entitled to remain in the country and so would not be eligible for welfare. Given the complex mix of factors, both institutional and behavioural, in determining welfare receipt our analysis simply asks how immigrants and natives differ in terms of receipt. We do not attempt to disentangle the relative impacts of institutional factors versus behavioural.

In looking at the means for our social welfare dummy variable amongst immigrants and natives, we find that 15 percent of the natives report participation in one of the four schemes; the corresponding figure for immigrants is just 7 percent. This implies that the immigrant population in Ireland differs from those in Germany and Sweden who had higher rates of welfare participation relative to natives (see Hansen and Lofstrom, 2003, and Riphahn, 2004, referenced above). As we also know that the immigrants in Ireland are more highly educated on average than the native population and that more highly educated people use welfare services less intensively, we need to explore if the education difference explains the social welfare difference.

In Table 7, we present the results from two probit regressions in which the dependent variable is the social welfare dummy variable and is equal to one if the individual was in receipt of one of the four payments and zero otherwise. We present the marginal impacts, as opposed to coefficients, for ease of interpretation. In Model 1, we use just one dummy variable to identify immigrants. As can be seen, we obtain a negative and significant impact for immigrants of 5 percent suggesting that immigrants are less likely to have been in receipt of payments controlling for factors such as education, gender and years of work experience. In Model 2, we break the immigrant group into those from English speaking and non-English countries but no difference between the two groups is found.

As discussed above, although we have found a statistically significant difference between immigrants and natives in terms of welfare participation, it is difficult to interpret this result in terms of the underlying causes. Part of the difference may be related to underlying propensities but part may also be related to differences in 
eligibility. Either way, the lower intensity of welfare participation by immigrants points to lower demands on the public finances at least through this avenue.

Table 7 here

As a final part of our analysis of immigrant welfare participation, we ran a tobit regression in which the dependent variable was the amount of welfare received over the previous twelve months under the four programmes in question. We are cautious in reporting this because any observation of lower amounts being received by immigrant in the previous twelve months, conditional on being in receipt of some payment, could be the result of being in Ireland for a limited period. As we do not have information on year or month of arrival, there is little that we can say about this. The tobit analysis produced a negative and significant coefficient on the immigrant dummy variable. In terms of marginal impact, immigrants who received some payment were estimated to receive $€ 281$ less than natives, controlling for education and years worked ${ }^{6}$. To the extent that some immigrants may not have been in Ireland for the previous twelve months, this estimate is downward biased but does point again to lower welfare usage for immigrants relative to natives.

\section{Section 6: Summary and conclusions}

We began the paper by suggesting that Ireland's rapid economic growth, when combined with the educational level of its immigrants, may have led to its immigrants avoiding earnings disadvantages or a greater need to be on welfare, relative to natives. In terms of earnings, our analysis points to earnings gaps even in these favourable circumstances. We have found that immigrants' hourly earnings are 18 percent lower than those of native employees, controlling for factors such as education and experience. When we look at this earnings difference for immigrants from English speaking and non-English countries, we find that the gap is much more pronounced for those from non-English speaking countries (3 percent versus 31 percent respectively). Looking within the group from non-English speaking countries, we find an hourly earnings disadvantage of 45 percent for immigrants from the $10 \mathrm{New}$ Member States of the EU. The corresponding figure for immigrants of the EU-15,

\footnotetext{
${ }^{6}$ The average amount received over the twelve month period in the sample was $€ 3,501$.
} 
excluding Ireland and the UK, is 27 percent and the same wage gap is found for immigrants from non-English speaking countries outside of the EU.

We explored whether the immigrant earnings gaps were related to lower returns to human capital acquired elsewhere and the evidence suggests that this is true in part. For the immigrant group as a whole, immigrants with third level degrees were found to earn 17 percent less than comparable natives. As regards welfare, Ireland does not appear to be experiencing any sort of immigrant-related drain on public resources. We have shown that on average immigrants use welfare services less intensively and that this difference remains even when we adjust for the higher levels of education among the immigrant population.

In the case of both earnings and welfare participation, one crucial element that is missing from our analysis is duration of time in Ireland for immigrants. As our data do not include this information, we have not been able to assess if the wage disadvantage reduces over time or if immigrants "assimilate into" welfare programme participation. In looking at occupational attainment among immigrants, Barrett and Duffy (2006) show that an interesting picture of immigrant experiences emerges when immigrants are divided up into arrival cohorts, with the earlier arrivals showing the strongest degree of labour market integration. It could well be that the earnings gap diminishes over time and given the high level of education among Ireland's immigrants, it might be expected that this will indeed happen. Monitoring this situation will be the next task for research in this area. 
Figure and Tables

Figure 1: Net Migration to Ireland, 1987 to 2006

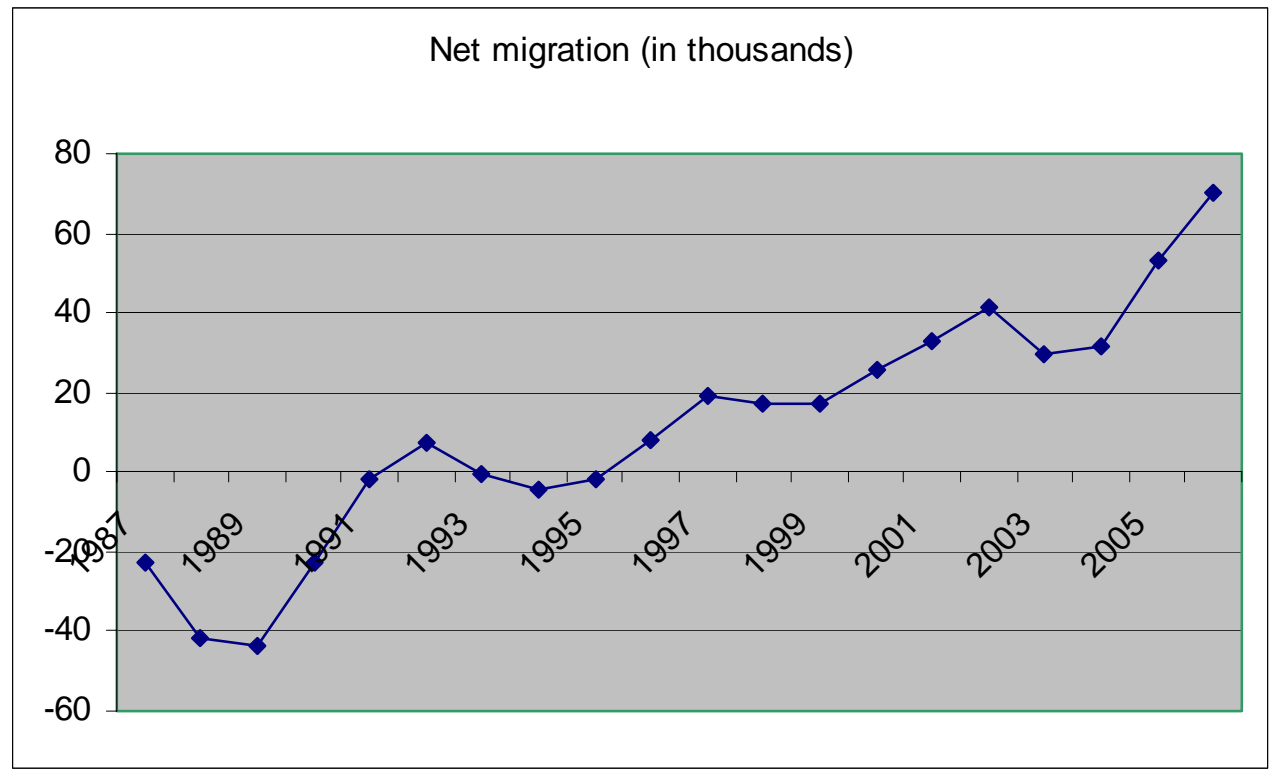

Table 1: Age Distribution of the Native and Immigrant Populations (\%s)

\begin{tabular}{lccc}
\hline \hline $\begin{array}{l}\text { Age Group } \\
\text { yrs })\end{array}$ & $\begin{array}{l}\text { EU-SILC } \\
\text { Irish }\end{array}$ & $\begin{array}{l}\text { EU-SILC } \\
\text { Immigrant }\end{array}$ & $\begin{array}{l}\text { QNHS } \\
\text { Immigrant }\end{array}$ \\
\hline $0-14$ & 22.0 & 15.8 & 22.6 \\
$15-19$ & 7.9 & 3.7 & 5.9 \\
$20-24$ & 6.3 & 8.9 & 9.9 \\
$25-34$ & 9.4 & 25.5 & 32.3 \\
$35-44$ & 12.5 & 18.5 & 19.6 \\
$45-54$ & 13.2 & 13.4 & 4.3 \\
$55-59$ & 6.1 & 4.5 & 1.6 \\
$60-64$ & 5.2 & 2.7 & 1.9 \\
$65+$ & 17.5 & 6.9 & 1.9 \\
Total & 100.0 & 100.0 & 100.0 \\
Mean & 38.3 & 34.3 & n/a \\
\hline $\mathbf{N}$ & $\mathbf{1 3 1 1 9}$ & $\mathbf{5 9 5}$ & $\mathbf{9 3 8}$ \\
\hline \hline
\end{tabular}


Table 2: Gender Distribution of the Native and Immigrant Populations (\%s)

\begin{tabular}{lccc}
\hline \hline & $\begin{array}{l}\text { EU-SILC } \\
\text { Irish }\end{array}$ & $\begin{array}{l}\text { EU-SILC } \\
\text { Immigrant }\end{array}$ & $\begin{array}{l}\text { QNHS } \\
\text { Immigrant }\end{array}$ \\
\hline Female & 51.1 & 55.3 & 50.6 \\
Male & 48.9 & 44.7 & 49.4 \\
Total & 100.0 & 100.0 & 100.0 \\
\hline $\mathbf{N}$ & $\mathbf{1 3 1 1 9}$ & $\mathbf{5 9 5}$ & $\mathbf{9 3 8}$ \\
\hline \hline
\end{tabular}

Table 3: Work Status Distribution of Native and Immigrant Populations (\%s)

\begin{tabular}{lccc}
\hline \hline & $\begin{array}{c}\text { EU-SILC } \\
\text { Irish }\end{array}$ & $\begin{array}{l}\text { EU-SILC } \\
\text { Immigrant }\end{array}$ & $\begin{array}{l}\text { QNHS } \\
\text { Immigrant }\end{array}$ \\
\hline Full-time employment & 38.1 & 42.7 & 40.6 \\
Part-time employment & 10.4 & 11.9 & 10.5 \\
Unemployed but Seeking Work & 2.6 & 3.6 & 4.7 \\
Unemployed but not Currently Seeking & 1.2 & 1.8 & 0.3 \\
Work & & & \\
Not Economically Active & 47.7 & 39.9 & 43.9 \\
Total & 100.0 & 100.0 & 100.0 \\
Participation Rate & 50.0 & 57.5 & 55.8 \\
Unemployment Rate & 5.1 & 6.3 & 8.4 \\
\hline$N$ & $\mathbf{1 0 0 1 0}$ & $\mathbf{4 9 4}$ & $\mathbf{7 2 6}$ \\
\hline \hline
\end{tabular}

Table 4: Distribution of Educational Attainment for the Native and Immigrant Labour Force (\%s)

\begin{tabular}{lccc}
\hline \hline & $\begin{array}{l}\text { EU-SILC } \\
\text { Irish }\end{array}$ & $\begin{array}{l}\text { EU-SILC } \\
\text { Immigrant }\end{array}$ & $\begin{array}{c}\text { QNHS } \\
\text { Immigrant }\end{array}$ \\
\hline Less than Leaving Cert & 35.7 & 14.1 & 9.4 \\
Leaving Cert and Non-Degree & 46.0 & 41.3 & 47.9 \\
Third Level Degree and Above & 18.3 & 44.6 & 42.7 \\
Total & 100.0 & 100.0 & 100.0 \\
\hline $\mathbf{N}$ & $\mathbf{5 0 9 2}$ & $\mathbf{2 6 9}$ & $\mathbf{3 6 1}$ \\
\hline \hline
\end{tabular}


Table 5: Wage Regressions (Dependent variable: log of hourly earnings)

\begin{tabular}{|c|c|c|c|c|c|c|}
\hline & \multicolumn{2}{|c|}{ Model 1} & \multicolumn{2}{|c|}{ Model 2} & \multicolumn{2}{|c|}{ Model 3} \\
\hline & Coef. & S. $E$ & Coef. & S. $E$ & Coef. & S. $E$ \\
\hline Constant & 1.85 & 0.03 & 1.86 & 0.03 & 1.85 & 0.03 \\
\hline Immigrant & -0.18 & 0.04 & & & & \\
\hline $\begin{array}{l}\text { Immigrant: English } \\
\text { Speaking Country }\end{array}$ & & & -0.03 & 0.06 & & \\
\hline $\begin{array}{l}\text { Immigrant: Non- } \\
\text { English Speaking } \\
\text { Country }\end{array}$ & & & -0.31 & 0.06 & & \\
\hline $\begin{array}{l}\text { Immigrant: Non- } \\
\text { English Speaking } \\
\text { EU-10 }\end{array}$ & & & & & -0.45 & 0.12 \\
\hline $\begin{array}{l}\text { Immigrant: Non- } \\
\text { English Speaking } \\
\text { EU-13 }\end{array}$ & & & & & -0.27 & 0.11 \\
\hline $\begin{array}{l}\text { Immigrant: Non- } \\
\text { English Speaking } \\
\text { Outside EU-25 }\end{array}$ & & & & & -0.27 & 0.08 \\
\hline Gender & 0.12 & 0.02 & 0.12 & 0.02 & 0.12 & 0.02 \\
\hline Years Worked & 0.04 & 0.00 & 0.04 & 0.00 & 0.04 & 0.00 \\
\hline$(\text { Years Worked })^{2}$ & 0.00 & 0.00 & 0.00 & 0.00 & 0.00 & 0.00 \\
\hline Leaving Cert** & 0.31 & 0.02 & 0.31 & 0.02 & 0.31 & 0.02 \\
\hline Third Level** & 0.85 & 0.03 & 0.86 & 0.03 & 0.86 & 0.03 \\
\hline $\mathrm{N}$ & Total In & $\mathrm{ts}=183$ & $\begin{array}{r}\text { English } \\
\text { Non-En } \\
\text { Adj }\end{array}$ & $\begin{array}{l}\text { ng }=82 \\
\text { peaking } \\
.28\end{array}$ & $\begin{array}{r}\text { EU- } \\
\text { EU- } \\
\text { Non-E } \\
\text { Adj. }\end{array}$ & $\begin{array}{l}22 \\
27 \\
=52 \\
.28\end{array}$ \\
\hline
\end{tabular}

Note: ** Omitted category is Primary Education or Less than Leaving Cert. 
Table 6: Wage Regressions with Interactions Included (Dependent variable: log of hourly earnings)

\begin{tabular}{|c|c|c|c|c|c|c|c|c|}
\hline & \multicolumn{2}{|c|}{ Model 1} & \multicolumn{2}{|c|}{ Model 2} & \multicolumn{2}{|c|}{ Model 3} & \multicolumn{2}{|c|}{ Model 4} \\
\hline & Coef. & S. E & Coef. & S. E & Coef. & S. $E$ & Coef. & S. $E$ \\
\hline Constant & 2.08 & 0.03 & 2.08 & 0.03 & 2.08 & 0.03 & 2.08 & 0.03 \\
\hline Immigrant & -0.12 & 0.06 & -0.16 & 0.09 & & & & \\
\hline $\begin{array}{l}\text { Immigrant: Non- } \\
\text { English } \\
\text { Speaking } \\
\text { Country }\end{array}$ & & & & & -0.26 & 0.08 & -0.32 & 0.12 \\
\hline Gender & 0.11 & 0.02 & 0.11 & 0.02 & 0.11 & 0.02 & 0.11 & 0.02 \\
\hline Years Worked & 0.04 & 0.00 & 0.04 & 0.00 & 0.04 & 0.00 & 0.04 & 0.00 \\
\hline$(\text { Years Worked })^{2}$ & 0.00 & 0.00 & 0.00 & 0.00 & 0.00 & 0.00 & 0.00 & 0.00 \\
\hline Third Level** & 0.67 & 0.03 & 0.67 & 0.03 & 0.67 & 0.03 & 0.67 & 0.03 \\
\hline $\begin{array}{l}\text { Immigrant*Third } \\
\text { Level }\end{array}$ & -0.17 & 0.09 & -0.16 & 0.09 & -0.13 & 0.12 & -0.11 & 0.12 \\
\hline $\begin{array}{l}\text { Immigrant* } \\
\text { Years Worked }\end{array}$ & & & 0.00 & 0.00 & & & 0.01 & 0.01 \\
\hline $\mathrm{N}$ & Adj. & $\begin{array}{l}5 \\
=0.24\end{array}$ & Adj. & 0.24 & Adj. & $\begin{array}{l}3 \\
=0.25 \\
\end{array}$ & Adj. & $=0.25$ \\
\hline
\end{tabular}

Note: ** Omitted category is less than third level degree. 
Table 7: Probit Results of Social Welfare Participation (Dependent Variable: Social Welfare Recipient)

\begin{tabular}{|c|c|c|c|c|}
\hline & \multicolumn{2}{|c|}{ Model 1} & \multicolumn{2}{|c|}{ Model 2} \\
\hline & $\begin{array}{c}\text { Marginal } \\
\text { Impact }\end{array}$ & Std. Error & $\begin{array}{l}\text { Marginal } \\
\text { Impact }\end{array}$ & Std. Error \\
\hline Immigrant & -0.05 & 0.02 & & \\
\hline Immigrant: English Speaking & & & -0.06 & 0.02 \\
\hline Country & & & & \\
\hline Immigrant: Non-English & & & -0.04 & 0.03 \\
\hline Speaking Country & & & & \\
\hline Gender & -0.03 & 0.01 & -0.03 & 0.01 \\
\hline Years Worked & 0.00 & 0.00 & 0.00 & 0.00 \\
\hline$(\text { Years Worked })^{2}$ & -0.00 & 0.00 & -0.00 & 0.00 \\
\hline Leaving Cert** & -0.06 & 0.01 & -0.06 & 0.01 \\
\hline Third Level** & -0.11 & 0.01 & -0.11 & 0.01 \\
\hline $\mathrm{N}$ & & & & \\
\hline LR chi2 & & & & \\
\hline Prob $>$ chi 2 & & & & \\
\hline Pseudo R2 & & & & \\
\hline
\end{tabular}

Note: ${ }^{* *}$ Omitted category is Primary Education or Less than Leaving Cert. 


\section{References}

Barrett, A., A. Bergin and D. Duffy (2006), "The Labour Market Characteristics and Labour Market Impacts of Immigrants in Ireland”, Economic and Social Review Vol. 37 No. 1

Barrett, A. and D. Duffy (2006), “A Note on the Educational Profile and Occupational Attainment of Immigrants in Ireland”, in Barrett, A., I. Kearney and Y. McCarthy (eds.) Quarterly Economic Commentary, Autumn, ESRI

Barrett, A., J. FitzGerald and B. Nolan (2002), "Earning Inequality, Returns to Education and Immigration into Ireland”, Labour Economics Vol. 9 No. 5

Bell, B.D. (1997), “The Performance of Immigrants in the United Kingdom: Evidence from the GHS”, Economic Journal Vol. 107 No. 441

Borjas, G. (1999), “The Economic Analysis of Immigration”, Chapter 28 in Ashenfelter, O. and Card, D. (eds.) Handbook of Labor Economics Vol. 3, Elsevier

Borjas, G. (1995), “The Economic Benefits of Immigration”, Journal of Economic Perspectives Vol. 9 No. 2

Borjas, G. (1987), "Self-Selection and the Earnings of Immigrants", American Economic Review, Vol. 77 No. 4

Borjas, G. (1985), “Assimilation, Cohort Quality and the Earnings of Immigrants”, Journal of Labour Economics, Vol. 3 No. 4

Central Statistics Office (2005), EU Survey on Income and Living Conditions (EUSILC), Dublin: CSO

Chiswick, B. (1978), "The Effect of Americanisation on the Earnings of Immigrant Men”, Journal of Political Economy, Vol. 86 No. 51

Chiswick, B. and P. Miller (2002), "Immigrant Earnings: Language Skills, Linguistic Concentrations and the Business Cycle”, Journal of Population Economics Vol.15 No. 1

Dustmann, C. and F. Fabbri (2003), "Language Proficiency and the Labour Market Performance of Immigrants in the UK”, Economic Journal, Vol. 113, No. 489

Fanning, B., S. Loyal and C. Staunton (2000), Asylum Seekers and the Right to Work in Ireland, Dublin: Irish Refugee Council

Hansen, J. and M. Lofstrom (2003), "Immigrant Assimilation and Welfare Participation: Do Immigrant Assimilate into or out of Welfare?”, Journal of Human Resources Vol. 38 No. 1 
McDonald, J.T. and C. Worswick, (1998), "The Earnings of Immigrant Men in Canada: Job Tenure, Cohort and Macroeconomic Conditions”, Industrial and Labor Relations Review Vol. 51 No. 3

Riphahn, R. (2004), “Immigrant Participation in Social Assistance Programs”, Applied Economics Quarterly Vol. 50 No. 4

Ruhs, M. (2005), Managing the Immigration and Employment of non-EU Nationals in Ireland, Paper No. 19, The Policy Institute, TCD

Shields, M. and S. Wheatley-Price (1998), "The Earnings of Male Immigrants in England: Evidence from the Quarterly LFS”, Applied Economics Vol. 30 pp. 11571168 